Volodymyr Muravskyi, Ph.D., Associate Professor, Accounting in Production Department, Ternopil National Economic University, Ternopil, Ukraine

Oleg Shevchuk,

Ph.D., Associate Professor, Accounting in Production Department, Ternopil National Economic University, Ternopil, Ukraine

Yuliya Sudyn,

Ph.D., Associate Professor, Accounting in Production Department, Ternopil National Economic University,

Ternopil, Ukraine

\title{
MANAGEMENT ACCOUNTING OF THE SETTLEMENTS WITH CONTRACTORS IN INNOVATIVE ENVIRONMENT OF BUSINESS COMMUNICATIONS
}

The purpose of the article is the research of the possibility the expediency of forming an innovational information space for establishes the effective communications between all parties to contractual relations, which is the basis for automation of management accounting the receivables and payables. The object of the research is the organization of the automated management accounting of settlements with counterparties in the company. The subject of the research is a set of theoretical, methodological and practical aspects of the automated management accounting of debtors and creditors payment by introducing a single integrated database of counterparties. Methods of analysis and synthesis are used to structure the domain of research, based on the identification of integral information field of business interaction and formalization of the automation processes of debtors and creditors payment accounting using communication technologies. Electronic communications provide information interaction of all debtors and creditors of the company, during which the accounting information is collected, processed and stored in a single database. The article is devoted to theoretical and practical aspects of management accounting automation of the settlements with counterparties. The questions of the accounting automation of the repayment of receivables and payables have been considered. Recommendations on the implementation of an innovational integrated database of counterparties at the company have been suggested in the article. The information model of an integrated database has been designed, which contains information about counterparties, the availability of contractual relations, the state of accounts receivable and creditors payable and the procedure for redemption. A single database acts as an information space of electronic interaction of all market participants in financial transactions. There is information exchange between suppliers, customers, banking institutions, legal and factoring organizations, government agencies and service of fiscal statistics. However, public access to a single database can lead to loss of confidential information, which requires the development of effective methods of information protection of the accounting system.

Keywords: management accounting, accounting automation, receivable and payables, settlements with counterparties, a single database of counterparties, innovative information environment, business communications. 
The urgency of the research. Informatization of social processes has led to the formation of large and global information environments. An integrated space unites many subjects of the information process around a common goal, which may involve effective communications establishing, information services obtaining or data searching and updating. There is an increasing number of innovative information services based on Internet technologies, whose task is to optimize the interaction of business entities. Through the Internet, modern enterprises search for contracting parties and consumers of products (works, services), inform state institutions about their activities. The active introduction of electronic money actualizes a gradual refusal of payment transactions. Invoices are sent and paid through the global information network by means of electronic money. Personnel can perform functional duties remotely, without being physically present in the territory of the enterprise. All information communications are carried out using modern communication technologies.

However, the simultaneous use of several network services without the possibility of mutual information exchange is unacceptable in the formation of a global information space. It's high time to shape a unified corporate innovative system of modern business with the integration of all information services.

Analysis of recent researches and publications. Historically, automation of accounting and monitoring processes was primarily involved in payment transactions. The software was used to automate accounting for the emergence and settlement of receivables and payables. At the same time, electronic business communication systems were developing, providing for Internet correspondence, mailing of business correspondence, joint implementation of work tasks, and the distancing of functional duties. The further direction of the automated systems of arrears accounting and monitoring development is the integration of accounting functions with the communication technologies of the contracting parties' interaction.

The need to create a common innovative environment for the receivables and payables accounting automation has been investigated by domestic scientists. For example, M.K. Tereshchenko justified that in order to automate debt it is necessary:

- to compile the information base of payables and receivables of settlement participants;

- to check in electronic form mutual requirements and obligations and find the most rational ways of mutual debts settlement;

- to carry out mutual settlements, gradually reducing the amount of debt;

- to keep records and accounts of the conducted mutual settlements [1, p. 11].

A significant achievement of the computer and communications technology use is ensuring monitoring of the timely debts payment. T.V. Chornak states that modern accounting computer programs allow monitoring the contractual maturity of debts in order to prevent violations in the terms of contracts $[2, p$. 59]. On the other hand, according to A.I. Koblianska, it becomes possible to promptly form pre-action claims against debtors. Debtors' failure in complying with the payment discipline and untimely lodging of claims on receivables may lead to a decrease in the volume of highly liquid working capital, and therefore to a violation of the enterprises' financial stability [3, p. 832].

Application of the system of banking communications "client-bank" additionally contributes to the growth of the level of control over settlement operations. Payment discipline is provided. The management of the enterprise owns operational information on the receipt of funds to banking accounts, allowing monitoring the repayment of receivables in the necessary temporary, monetary, actuarial cuts for each counterparty, bank account, business transaction, which led to an increase in debts [4]. Due to modern electronic communications, the enterprise's management is able to promptly form debt claims.

At a time when Ukrainian scientists are considering the problems of automating settlements with counterparties locally, foreign scientists think more globally on the scale of the formation of large information environments. For example, the team of authors led by Carla Wilkin proved the impact of online communications with contractors on the formation of company's added value of the [5, c.38-39]. 
The direct influence of state institutions and stakeholders through the global information systems on accounting, control and analytical processes of the enterprise is explored. Vasarhelyi A. Miklos, Kogan Alexander and Tuttle M. Brad. in the formation of the global information system found the problem of structuring large amounts of accounting information about counterparties. Scientists offered to accumulate data in the block-chain structure to provide quick access and prevent loss of information [6, c. 385]. On the wave of block-chine technologies actualization, Yunsen Wang and Alexander Kogan developed an accounting and controlling method of the electronic transactions between counterparties. It is proposed to create a global information system of electronic communications based on block-chine technology in order to ensure reliability, confidentiality, efficiency and protection of information [7, c.28]. John Campbell developed a methodology for identifying and authorizing participants of contractual relationships in the business communications system. The author formed a standard for making personal information about business activities in a common information space [8, c. 25-26].

The main role in the formation of large information systems of business communications Ogan Yigitbasioglu devotes to management accounting. The influence of management accounting on the information filling of global information systems is explored [9, c.22]. Markus Granlund considers management accounting as an interface that combines information technologies with information systems and participants in the communication process [10, c.23]. Accounting is a communicator, integrator and communication channel for information interaction between counteragents and other institutional entities. Additionally, Nicolaou I. Andreas emphasizes the global character and internationality of the integrated information systems formation and uses based on the credentials database [11, c.119-120].

Selection of previously unsettled parts of the general problem. Efficiency, timeliness and completeness of informing responsible persons on the receivables and payables status depend on the use of the full-featured software. Scientists consider the use of modern software products as a way to reduce the complexity of accounting for accounts receivable and payables, and the introduction of communication technologies proposed to apply to ensure the control over the timeliness of settlements with debtors and creditors [12, 13, 14]. Communication and organizational aspects of the information services formation for business communications at meso and macro levels in order to automate the accounting and monitoring of relationships with counterparties are still being neglected.

The main aim is to justify the expediency of forming a common innovative information space, aiming at establishing effective communications between all parties to contractual relations, which is the base for automating the receivables and payables accounting and monitoring. The purpose of the research is implemented through the fulfilment of a number of tasks:

- clarifying the possibility of forming a single database of counterparties and determining the content of its content with the purpose of organizing an innovative information space for business communication;

- studying the procedure of electronic contractual arrangements' conclusion and carrying out electronic money transactions for the purpose of management accounting and control of settlements with debtors and creditors;

- development of methods for automation of management accounting and control of receivables and payables, their mutual offset, calculation and formation of doubtful debts' reserve;

- submission of proposals on information interaction of the system of management accounting and control of business entities with banking and factoring institutions, budgetary institutions that are controlled by tax authorities, and the statistical service.

The basic material. Current information should reflect all aspects of the business entities' activities that do not constitute commercial confidentiality. The combination of management, accounting and planning data with information on social responsibility and sustainable development enables the formation of an integrated database of contractors. Access to a single information base should be provided to all enterprises, institutions, organizations and individual entrepreneurs via the Internet [15, c.744]. The 
Z.-M. V. Zadorozhnyi, V. V. Muravskyi, O. A. Shevchuk, Y. A. Sudyn. Management Accounting of the Settlements with Contractors in Innovative Environment of Business Communications

integrated system should act as an area of general communication exchange between the parties to the contractual relationship. A significant number of companies are already using electronic communications systems to communicate with suppliers and customers. The share of European enterprises with business online communications reached $18 \%$ in 2017 (Table 1).

Table 1 - Enterprises whose business processes are electronically linked to those of their suppliers and/or customers in Europe (\%) [16]

\begin{tabular}{|c|c|c|c|c|c|c|c|}
\hline Geo & \multicolumn{7}{|c|}{ Time } \\
\hline & 2008 & 2009 & 2010 & 2012 & 2014 & 2015 & 2017 \\
\hline EU & 16 & 15 & 18 & 23 & 17 & 17 & 18 \\
\hline Eurozone (19 countries) & 17 & 16 & 20 & 22 & 18 & 18 & 19 \\
\hline Austria & 20 & 14 & 14 & 22 & 18 & 15 & 16 \\
\hline Belgium & 35 & 33 & 34 & 32 & 22 & 24 & 26 \\
\hline Bulgaria & 14 & 13 & 18 & 31 & 18 & 18 & 17 \\
\hline UK & 7 & 6 & 7 & 26 & 13 & 12 & 12 \\
\hline Greece & 21 & 11 & 21 & 25 & 11 & 15 & 10 \\
\hline Denmark & 22 & 19 & 17 & 21 & 26 & 30 & 23 \\
\hline Estonia & 13 & 13 & 11 & 15 & 13 & 15 & 15 \\
\hline Ireland & 11 & 9 & 13 & 17 & 17 & 14 & 12 \\
\hline Iceland & 10 & - & 7 & 14 & 16 & - & 7 \\
\hline Spain & 20 & 14 & 17 & 21 & 18 & 17 & 17 \\
\hline Italy & 21 & 22 & 22 & 23 & 15 & 13 & 11 \\
\hline Cyprus & 8 & 8 & 8 & 16 & 13 & 17 & 17 \\
\hline Latvia & 20 & 22 & 34 & 43 & 7 & 8 & 6 \\
\hline Lithuania & 29 & 27 & 34 & 37 & 25 & 24 & 28 \\
\hline Luxembourg & 23 & 20 & 27 & 31 & 17 & 18 & 18 \\
\hline Macedonia & - & - & - & 33 & 14 & 12 & - \\
\hline Malta & 19 & 18 & 23 & 20 & 12 & 13 & 11 \\
\hline Netherlands & 13 & 13 & 5 & 15 & 18 & 21 & 19 \\
\hline Germany & 12 & 13 & 26 & 23 & 23 & 25 & 30 \\
\hline Norway & 22 & 25 & 25 & 33 & 23 & 20 & 16 \\
\hline Poland & 14 & 13 & 17 & 25 & 19 & 17 & 21 \\
\hline Portugal & 31 & 30 & 40 & 51 & 24 & 17 & 17 \\
\hline Romania & 7 & 10 & 13 & 14 & 8 & 10 & 7 \\
\hline Serbia & - & - & - & - & 77 & - & - \\
\hline Slovakia & 20 & 28 & 27 & 39 & 22 & 21 & 15 \\
\hline Slovenia & 27 & 18 & 19 & 24 & 18 & 14 & 15 \\
\hline Hungary & 14 & 10 & 11 & 11 & 10 & 9 & 9 \\
\hline Finland & 20 & 18 & 20 & 27 & 21 & 22 & 22 \\
\hline France & 12 & 11 & 13 & 13 & 11 & 13 & 13 \\
\hline Croatia & 36 & 42 & 53 & 47 & 30 & 24 & 19 \\
\hline Czech Republic & 12 & 13 & 15 & 15 & 22 & 21 & 12 \\
\hline Sweden & 27 & 30 & 27 & 31 & 13 & 13 & 13 \\
\hline
\end{tabular}


However, the low level of information technology implementation in the Ukrainian enterprise's activities is a barrier to the development of the innovative business environment. It is expedient to use tax information systems as a basis for forming the innovative communication environment In Ukraine. Much of the data on business entities and their interaction is already contained in a single database of accounting data. However, the accounting information has an occasional non-systemic nature and applies in most cases only to the taxes calculation and administration. In order to optimize accounting at the enterprise, it is useful to supplement the existing information with various data on contracting parties with which the enterprise has commercial relations. The significant detailing of accounting data in the context of the computer and communications technology use provides the enterprise with quite significant possibilities of automating settlements accounting with debtors and creditors.

It is appropriate to access the common innovative information space on the basis of a digital signature similar to the use of a tax electronic key. Each enterprise can independently determine the list of officials who will be allowed access to the integrated database. In most cases, owners, heads, accountants, managers and cashiers will be able to use information resources regardless of the form of the enterprise ownership. In case the employee is dismissed or transferred to another position with a lower level of access to the accounting information, it is necessary to inform the state registrar on the digital signature cancellation. On the part of government regulatory authorities, access is provided to civil servants in order to communicate with taxpayers and tax administration. All electronic keys are subject to strict regulation by the issuer with control over the validity periods and rights of access to information.

It is advisable to integrate the possibility of information interaction into modern software in order to automate management and accounting at the enterprise. By developing applications that provide access to the innovative information space of business communication, it is possible to expand the functional apparatus of already existing software products. Relevant computer programs are already partially suitable for information integration with a single database. All contemporary software developers provided for the possibility to exchange information on accrued and paid taxes with the fiscal service. In such computer programs, agreements are the base of accounting and monitoring of settlements with the contracting parties. Electronic registration of contractual relations is the basis for monitoring the timing of contracts performance, receivables and payables repayment. The scheme of the information content of the integrated database for the purposes of automation of accounting and monitoring is presented in Fig. 1.

The process of electronic business communication involves the interactive interaction of the enterprise via an innovative information environment with other parties in the contract process. Initially, an integrated database can be used as a business directory. It is advisable to provide the customer of goods (works, services) with a possibility to search for a contracting party through the Internet according to various criteria. In the context of the territorial location, public reliability rating, price orientations, product assortment, the company manager can choose a contracting party with which it is profitable to conclude an agreement. Moreover, business debates on contractual terms are allowed via a public chat. In the future, all the terms of the contractual relationship are determined with the simultaneous creation of an electronic duplicate of the agreement. If necessary, the contracting party is able to make amendments and corrections to the electronic document until the consent of all participants in the contract process is given. The final stage of the approval of the electronic agreement terms is the digital signature of the responsible person. 
Z.-M. V. Zadorozhnyi, V. V. Muravskyi, O. A. Shevchuk, Y. A. Sudyn. Management Accounting of the Settlements with Contractors in Innovative Environment of Business Communications

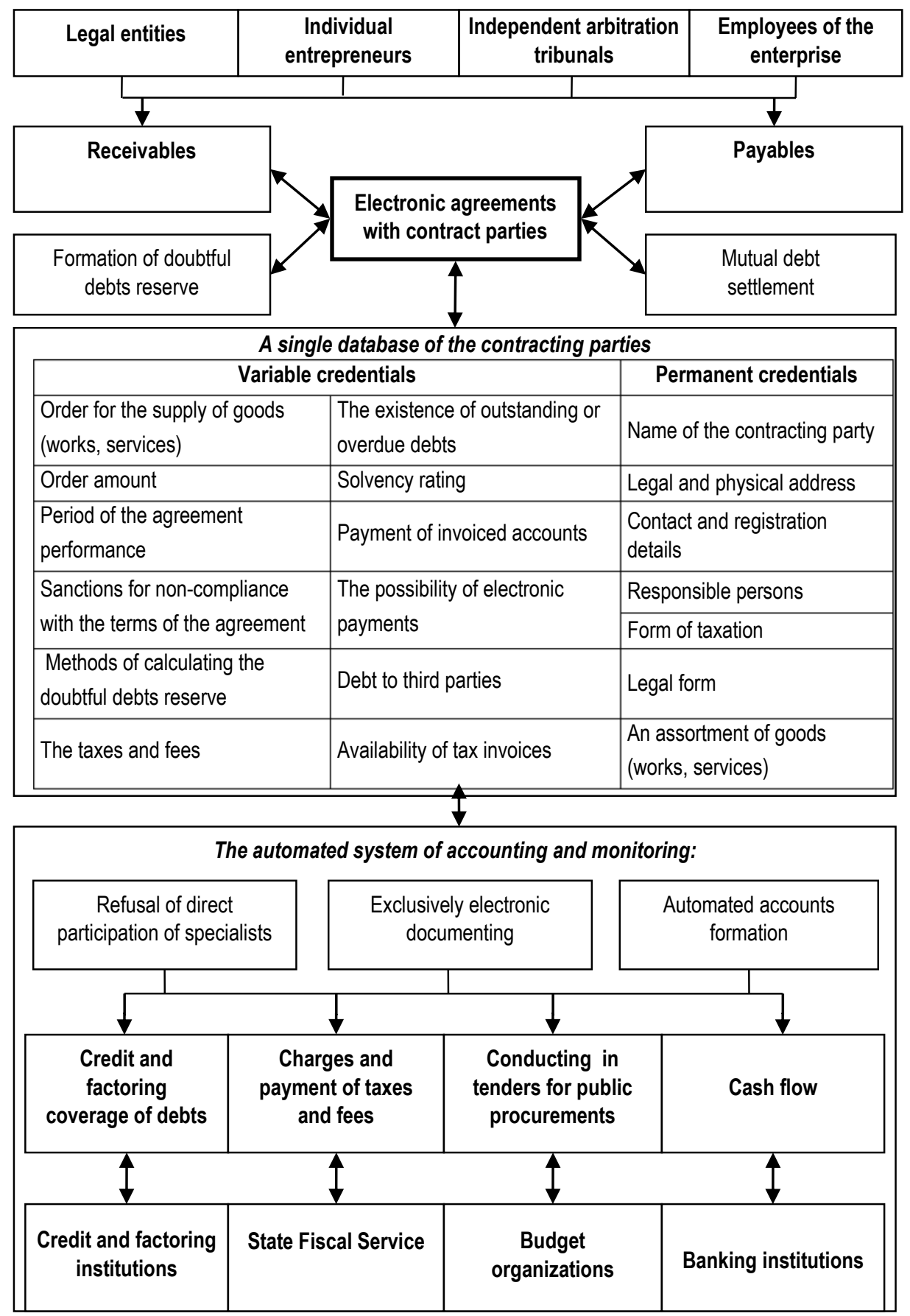

Figure 1 - Information model of the innovative environment of business communications for the purposes of automation of accounting and monitoring of enterprise debt 
In case one of the parties to the contractual process requires revision or violates the terms of the agreement, it is advisable to automatically send a request to the judicial authorities in order to appeal against the contracting party's actions. It is advisable to include independent non-state arbitrators in the innovative information space, who will be able to resolve disputes arising from civil and economic legal relations. Independent judicial bodies which officially work in the legal field of Ukraine can function as arbitration courts. Resolving economic disputes on the basis of the principles of anonymity, distancing takes place without the need to be present in court buildings. By common consent of all parties to the contractual relationship, information on the terms of the agreement and the evidence of the parties to the dispute should be sent via the Internet to the arbitration court. In case the contracting parties did not agree, then the terms of the agreement are appealed through a traditional judicial procedure in the system of courts of general jurisdiction.

It is recommended to use the common information space while organizing procurements by state institutions. Business entities of state ownership may place orders for the supply of products (works, services). Similar to the independent public procurement site "Prozzoro", electronic tenders can be announced in the software for the enterprise's management accounting and control [17].

Business entities submit requests for participation in the bids through the integrated database. The best offer for the supply of products (works, services) of all available is determined automatedly. The automated system recommends to the state enterprise to legalize contractual relations. In case of dissatisfaction with the results of announced tenders to a budgetary institution, it is expedient to allow once refuse to conclude an agreement. The mandatory involvement of all government institutions in a single database will eliminate fraud with government procurements.

The major information on contractual relations for the accounting and monitoring system is the contracting of the products (works, services) delivery time, which affects the conditions for recognizing the debt and ways to repay it. In the accounting system, it is necessary to set up the function of informing on the number of days remaining until the expiration of the agreement terms performance. Thus, there is an opportunity to monitor the timely performance of the agreement, which will help to avoid penalties for the untimely delivery of products (works, services).

Information obtained from a single database on the date of receipt or disposal of inventories is the basis for the automated planning of production and sales of the system "just in time". Quite often the enterprise does not have the possibility to store a significant amount of production stocks or finished products. Ineffective planning of the need for material value can become a threat to the uninterrupted activity of the enterprise. When receiving a signal message on the critical level of commodity and material values in an enterprise warehouse, it is advisable to automatically formulate a request for their stock replenishment.

In case information on the new order appeared, the responsible persons are informed of the need to start up production equipment. Moreover, an automated system of accounting and monitoring should be entrusted with the automatic initiation of the production process started in order to fulfill the contractual obligations. In other words, the manufacturing of products (performance of works, services) automatically begins only after the order is received or the contracting party made the payment.

The account specialist should be given an opportunity to create electronic samples of the invoices in the common business communication innovative environment. Through a single database, the invoices are sent to payers. Henceforth, the system of automated accounting and monitoring will monitor the payment of the account through an integrated system of information interaction with banking institutions "client-bank". At the same time, it is advisable to form electronic primary documents and records in accounts on the occurrence of receivables and payables and their settlement in an automated system of accounting and monitoring. After changes in the integrated database are verified by the responsible persons, the accounts come into force. 
At the same time, control over accounts receivable with automation of monitoring of counterparties' payment reliability and accounting for the provision of doubtful debts is provided. On the basis of the accumulated information on solvency and payment discipline of debtors in a single database, it is necessary to predict the possibility of forecasting the probability of non-repayment of actual debts. While choosing a counterparty, it is possible to ascertain the debtor's rating, which will serve as the basis for refusing to cooperate with an unreliable enterprise. Based on information on the number of accounts receivable from potential counterparties, automated solvency control is implemented. The company has an effective mechanism for avoiding losses from the repayment of receivables due to the refusal to cooperate with unscrupulous debtors with a low solvency rating. All business entities will monitor business reputation in order to attract counterparties to cooperate.

Data from the integrated innovative environment of business communications on the amounts and timing of debts non-payment should also be used for the automated formation of doubtful debts reserve. Depending on the rating of the contracting party's solvency, the accumulated experience of the terms and amounts of unpaid debts chosen in the accounting policy of the method for calculating the reserve, it is possible to determine the need for its formation [18, c.482]. The formation of an integrated innovative space makes it possible to automate the accounting and monitoring the netting. In case receivables are paid, it is advisable to check the status of settlements with the contracting parties. In case of existing payables that can cover the number of receivables, it is efficient to initiate automatic cancellation of debts between parties to contractual obligations. In the software, the accountant is previously expected to obtain permission for a business transaction conducting.

However, the global nature of the common information field of all business entities can also attract other contracting parties to the mutual offset process. The automated system of accounting and monitoring is able to search for third parties who have a common contracting party. The availability of receivables and payables to many participants of contractual relations contributes to the phased debts cancellation of some business entities to others. Debts settlement is carried out until the minimization of the total amount of debts of all market participants cooperating with each other. In other words, the task of an integrated innovative environment is to form an ideal model for mutual settlement of all types of debt.

Factoring and banking organizations are recommended to be provided with access to a single database. In the general innovative environment, it is possible to post proposals of financial and credit institutions to cover receivables and payables. After assessing the solvency of each occurrence of payables, the management of the business entity may resort to debt restructuring in favour of attracting loans from banks. Similarly, the company may apply factoring services for a counterparty with a low credit rating or a significant delay in payment of invoices. Considering the need to speed up the turnover of the company's debts, electronic consent is given to factoring or credit coverage of debts. Participants of contractual relations jointly approve the most optimal model of lending and factoring on the basis of competitive selection between proposals of financial and credit organizations. In the software product for the automation of managerial accounting and control an electronic contract for the provision of factoring and banking services with the automatic formation of records on posting accounts is concluded.

Information on contractual relations and settlements with contracting parties should be automatically sent to the fiscal service in order to verify the reliability and completeness of the taxes calculation. The system is able to trace the facts of payment (receipt) of cash or shipping (capitalization) of inventories, which is taken into account while determining the amount of taxes. After tax liabilities have been charged, it is advisable to perform automatic data verification with an integrated innovative environment. Since all the accounting information has been promptly received by the controlling authorities, it is impossible to fraud in order to reduce the tax liability or evade taxes and fees.

Conclusions and directions for further research. An advanced area of the society informatization is the formation of an integrated innovative space, access to which is advisable to provide legal entities 
and individuals (business entities). As a basis for building a unified database of contracting parties, it is recommended to use a tax information system aiming at transferring accounting data to supervisory agencies on the taxes charges and payments. Access to the information environment can be implemented through the use of personalized tax electronic keys.

It is advisable to enter all accounting data on contracting parties, contracts for the supply of goods (works, services), receivables and payables and cash payments in a single database. Integrated space acts as a communication platform for contractual relations. Through the mechanism of personal digital signatures, representatives of enterprises can conclude electronic agreements.

The single innovative space allows establishing effective communication connections not only with contracting parties of the enterprise but also with state supervisory institutions in order to monitor taxes charges and payments; with banking and factoring institutions in order to attract financial services of payables and receivables covering; with statistical service in order to inform about the results of the business entities' activities; with independent judicial bodies (arbitration tribunals) in case of violation of conditions or non-fulfillment of contractual relations; with budget organizations regarding participation in announced tenders for public procurement and the like. However, general access to the integrated database can result in loss of confidential information, which requires further research in the field of information protection of the automated system of accounting and monitoring at the enterprise.

Tereshchenko M. K. (2014). Deiaki aspekty udoskonalennia obliku, analizu ta audytu debitorskoi zaborhovanosti pidpryiemstva [Some aspects of improvement of accounting, analysis and audit of accounts receivable of an enterprise]. Ekonomichnyi visnyk. Economic Bulletin, 1, 107-113 [in Ukrainian].

Chornak T. V. (2010). Udoskonalennia otsinky debitorskoi zaborhovanosti ta yii vidobrazhennia u zvitnosti [Improvement of the assessment of receivables and their reporting in reporting]. Naukovyi visnyk Uzhhorodskoho natsionalnoho universytetu. - Scientific herald of Uzhgorod National University, 29, 56-59 [in Ukrainian].

Koblianska O. I. (2009). Metodolohichni aspekty obliku ta audytu debitorskoi zaborhovanosti [Methodological aspects of accounting and auditing of receivables]. Visnyk Kyivskoho natsionalnoho universytetu imeni Tarasa Shevchenka. - Bulletin of the Taras Shevchenko National Taras Shevchenko University, 28, 77-78 [in Ukrainian]

Moskaliuk H. O. Oblik ta kontrol debitorskoi zaborhovanosti: isnuiuchi problemy ta shliakhy yikh vyrishennia [Accounting and control of receivables: existing problems and ways of their solution]. Retrieved from: <http://dspace.oneu.edu.ua/jspui/bitstream/ 123456789/1754/1.pdf.> [in Ukrainian].

Wilkin L. Carla, Campbell John, Moore Stephen and Simpson Jason. (2018). Creating value in online communities through governance and stakeholder engagement. International Journal of Accounting Information, 29, 37-58 [in English].

Vasarhelyi A. Miklos, Kogan Alexander and Tuttle M. Brad. (2015) Big Data in Accounting: An Overview. Accounting Horizons 29, No. 2, 381-396 [in English].

Wang Yunsen and Kogan Alexander. (2018). Designing confidentiality-preserving Blockchain-based transaction processing systems. International Journal of Accounting Information Systems, 27, 22-32 [in English].

Campbell John. (2008). The Development of a B2G Online Authentication Standard: a design perspective of the policy consultation process. Australasian Journal of Information Systems; Vol 14, No 2, 14-28 [in English].

Yigitbasioglu Ogan. (2016). Firms information system characteristics and management accounting adaptability. International Journal of Accounting \& Information Management, 24, 20-37 [in English].

Granlund Markus (2009). On the interface between accounting and modern information technology. Uniprint, Turku, 70 [in English].

Andreas I. Nicolaou (2011). Integrated Information Systems and Interorganizational Performance: The Role of Management Accounting Systems Design. Advances in Accounting Behavioral Research. - Emerald Group Publishing Limited, 14, 117-141 [in English].

Volynets O. O. (2009). Kharakterystyka systemyanalitychnoho obliku zoboviazan ta metodyka yii udoskonalennia v umovakh elektronnoi obrobky ekonomichnoi informatsii [Characteristics of the system of analytical accounting of obligations and the method of its improvement in the conditions of electronic processing of economic information]. Visnyk Khmelnytskoho natsionalnoho universytetu. Ekonomichni nauky. - Bulletin of the Khmelnitsky National University. Economic sciences, Vol. 2, №5, 151-153 [in Ukrainian]

Zhytna I. P. And Sadovnikov O. A. (2010). Suchasni tekhnolohii udoskonalennia systemy avtomatyzatsii obliku ta upravlinnia vyrobnytstvom. [Modern technologies of improvement of accounting automation and production management system]. Upravlinnia rozvytkom. - Development management, 3, 126-128 [in Ukrainian].

Rikhardsson Pall. (1998). Information systems for corporate environmental management accounting and performance 
Z.-M. V. Zadorozhnyi, V. V. Muravskyi, O. A. Shevchuk, Y. A. Sudyn. Management Accounting of the Settlements with Contractors in Innovative Environment of Business Communications

measurement. Greener Management International, 98, 51-60 [in English].

Miller Louise. (2012). An Internet-based Accounting Information Systems Project. American Journal Of Business Education, 5 (6), 743-752 [in English].

Enterprises whose business processes are automatically linked to those of their suppliers and/or customers. - Eurostat. Retrieved from: <http://ec.europa.eu/eurostat/tgm/table.do?tab=table\&init=1\&plugin=1\&language=en\&pcode=tin00115.>

ProZorro - pilotnyi proekt elektronnoi systemy publichnykh zakupivel, shcho dozvoliaie onlain prodavaty Derzhavi [The pilot project for an electronic public procurement system that allows online sales to the State]. Retrieved from: <http://www.niss.gov.ua/articles/1091.> [in Ukrainian].

Tsai L.-K., Tserng H.-P., Liao H.-H., Chen P.-C. and Wang W.-P. (2012). Integration of accounting-based and option-based models to predict construction contractor default. Journal of Marine Science and Technology (Taiwan), 20, 479-484 [in English].

3.-М. В. Задорожний, д.е.н., професор, Тернопільський національний економічний університет (Тернопіль, Україна);

B. В. Муравський, к.е.н., доцент, Тернопільський національний економічний університет (Тернопіль, Україна);

О. А. Шевчук, к.е.н., доцент, Тернопільський національний економічний університет (Тернопіль, Україна);

Ю. А. Судин, к.е.н., доцент, Тернопільський національний економічний університет (Тернопіль, Україна).

Управлінський облік як елемент налагодження відносин 3 контрагентами в інноваційному середовищі ділових комунікацій

Єдина база даних використовується як інфформаційний простір електронної взаємодії всіх учасників ринку у фінансових операціях, що забезпечує інфоормаційний обмін між постачальниками, клієнтами, банківськими установами, юридичними та фракторинговими організаціями, державними установами та службою фіскальної статистики. Проте загальний доступ до єдиної бази даних може призвести до втрати конфріденційності інфрормації, що вимагає розроблення ефективних методів захисту інформації в системі бухгалтерського обліку. В статті досліджуються можливості формування інноваційного інформаційного простору для встановлення ефеективних комунікацій між усіма сторонами договірних відносин, що є основою для автоматизації управлінського обліку дебіторських та кредиторських зобов'язань. В статті надано рекомендації з впровадження інтегрованої бази даних про контрагентів на підприємстві. Проведено аналіз теоретичних, методологічних та практичних аспектів автоматизованого управлінського обліку виплат боржників та кредиторів шляхом впровадження єдиної інтегрованої бази даних контрагентів. За допомогою методів аналізу та синтезу здійснюється структурування сфрери досліджень, виходячи з ідентифікації інтегрального інформаційного поля ділової взаємодії та формалізації процесів автоматизації обліку платежів боржників та кредиторів за допомогою комунікаційних технологій. Розроблено інформаційну модель інноваційної інтегрованої бази даних, в якій міститься інфформація про контрагентів, наявність договірних відносин, стан дебіторської $і$ кредиторської заборгованості та порядок їх погашення. В роботі зроблено висновок, що електронні комунікації забезпечують інформаційну взаємодію всіх боржників та кредиторів компанії, під час якої збирання, обробка та зберігання бухеалтерської інформації здійснюється в єдиній базі даних.

Ключові слова: управлінський облік, автоматизація обліку, дебіторська та кредиторська заборгованість, розрахунки з контрагентами, єдина база даних про контрагентів, інноваційне інформаційне середовище, ділові комунікації. 